\title{
CITRININOTOXINOGENICITY OF PENICILLIUM SPP. ISOLATED FROM DECAYING APPLES
}

\author{
Stjepan Pepeljnjak ${ }^{1 *}$; Maja Šegvić1 ${ }^{\text {; Ladislav Ožegović }}{ }^{2}$ \\ ${ }^{1}$ University of Zagreb, Faculty of Pharmacy and Biochemistry, Department of Microbiology, Zagreb, Croatia. \\ ${ }^{2}$ Academy of Sciences and Arts of Anubih, Sarajevo
}

Submitted: November 23, 2000; Returned to authors for corrections: May 03, 2001; Approved: June 10, 2002

\begin{abstract}
A study on the occurrence of citrinin and citrinin production ability of Penicillium spp. isolated from decaying apples collected from households in Croatia was carried out. Among 100 samples of apples, 37 strains of Penicillium spp. were found, including P. expansum, P. roqueforti, P. implicatum and P. purpurogenum. Citrinin production in liquid yeast medium by 11 strains of $P$. expansum varied in a range of 0.07 to 9.00 $\mathrm{mg} \cdot \mathrm{kg}^{-1}$. Citrinin was isolated from $19 \%$ of apple samples in range of 0.05 to $0.24 \mathrm{mg} \cdot \mathrm{kg}^{-1}$. Antimicrobial activity of isolated citrinin, evaluated through tests on Bacillus subtilis, presented inhibitory zones varying from $5 \mathrm{~mm}$ to $1 \mathrm{~cm}$. Minimal inhibitory concentrations (MIC) were $0.0072 \mu \mathrm{g} \cdot \mathrm{mL}^{-1}$ for bacteriostatic effect, and $0.0144 \mu \mathrm{g} \cdot \mathrm{mL}^{-1}$ for bactericidal effect.
\end{abstract}

Key words: citrinin, Penicillium expansum, decaying apples, antimicrobial activity.

\section{INTRODUCTION}

Citrinin is a mycotoxin produced by a wide variety of Penicillium and Aspergillus species. In particular, it can be produced by the apple-decaying mould, Penicillum expansum (5).

Apples (Malus domestica) are a major food crop, with 40 million tonnes being produced in the world (10). Therefore, post harvest decay of apples has an enormous economic significance. The most common identifiable disease of apples is the blue mould, caused by Penicillium expansum. The infection often occurs while the apples are still on the tree, but remains latent for a long period, becoming visible only after long period of storage. The infection may occur through wounds, lenticels, or open calyx, and sometimes via airborne spores, or in contact with contaminated soil in storage containers, or via watering systems. Penicillium expansum seems to occur more frequently than other penicillia on apples, growing faster and causing larger lesions (15). The optimal growth for Penicillium expansum is $25^{\circ} \mathrm{C}$. It cannot grow above $37^{\circ} \mathrm{C}$. Spores can infect apples even at $0^{\circ} \mathrm{C}$ and germinate during storage at $0^{\circ} \mathrm{C}$.
When decayed fruits are used, commercially processed apple juice may contain different toxic metabolites, such as patulin and citrinin. The kidney seems to be the primary site of action of citrinin, which also affects the liver metabolism (4). The International Agency for Research on Cancer (IARC) classifies citrinin in group 3 because of limited evidence on carcinogenicity for animals and no data for humans (6). However, the presence of citrinin and other toxic metabolites in food, regardless the concentration, must be considered a potential human health hazard.

The objective of this experiment was to study the occurrence of citrinin in decaying apples used in production of apple juices, especially in individual households, estabilishing the antimicrobial activity of citrinin in tests on Bacillus subtilis. Citrinin production ability of Penicillium species isolated from these apple samples was also studied.

\section{MATERIALS AND METHODS}

One hundred samples of apples were collected from households in Croatia. Some of the samples presented visible fungal infection and blue mould symptoms.

\footnotetext{
* Corresponding author. Mailing address: Department of Microbiology, Faculty of Pharmacy and Biochemistry, University of Zagreb, A. Kovačića 1., 10000 - Zagreb, Croatia. Tel./Fax (+385) 14636371.
} 
Samples were plated on Sabouraud agar (5 parts from each sample) for analysis of contamination intensity. Some samples with visually detectable mould colonies were directly plated on agar plates (Czapek, Malt, Potato-Sucrose agar), and incubated at $25^{\circ} \mathrm{C}$ for 6-10 days. The isolated Penicillium species were determinated in accordance with keys $(2,13,14)$.

Citrinin production ability by Penicillium expansum, $P$. roqueforti, $P$. implicatum and $P$. purpurogenum strains was examined in vitro on liquid yeast medium (sucrose $40 \mathrm{~g}$, yeast extract $20 \mathrm{~g}$, water $1000 \mathrm{~mL}$ ). One $\mathrm{mL}$ of suspension of conidia $\left(10^{8} \cdot \mathrm{mL}^{-1}\right)$ from each Penicillium strain was inoculated in sterile liquid yeast medium $(50 \mathrm{~mL})$, incubated at $25^{\circ} \mathrm{C}$ for $10-14$ days with daily shaking.

Citrinin was extracted from apple samples and liquid yeast medium with Penicillium strains using a multitoxin method (1).

Validation of the extraction procedure was performed by addition of pure citrinin $(0.9,1.8,3.6,9.0$ and $18 \mu \mathrm{g})$ to liquid yeast medium $(50 \mathrm{~mL})$ and homogenisation in acetonitrile and water (9:1) for 10 minutes. From each filtrated sample, $50 \mathrm{~mL}$ was treated with $\mathrm{n}$-hexane $(2 \times 25 \mathrm{~mL})$ to remove the lipids. Sodium hydrogen carbonate $(25 \mathrm{~mL})$ and water $(25 \mathrm{~mL})$ were added into samples $(\mathrm{pH}=8-9)$ and extracted with chloroform $(25 \mathrm{~mL})$. Hydrochloric acid $(20 \mathrm{~mL})$ was added to the alkalin fraction and extracted with chloroform $(2 \times 20 \mathrm{~mL})$. The chloroform fraction was filtrated through sodium sulphate, evaporated to dryness, and dissolved in $0.2 \mathrm{~mL}$ of chloroform for Thin Layer Chromatography (TLC) analysis.

TLC was performed on silica gel $\mathrm{H}$ plate (Sigma), using acetone/ethyl acetate/water (10:10:4) as mobile phase (8). Prepared extracts and pure citrinin standard solution (Sigma) $\left(\mathrm{C}=180 \mu \mathrm{g} \cdot \mathrm{mL}^{-1}\right)$ were spotted on silica plates and analysed. Citrinin was visualised as yellow-green spot under UV light $(366 \mathrm{~nm})$ with retention factor (Rf) 0.5 . Quantification was carried out by visually comparing the fluorescence intensity of the extracted citrinin to that presented by the citrinin standard solution in different concentrations. The percentage of recovery varied between $33.3 \%$ and $72.2 \%$ (Table 1). All measurements were performed in duplicates. Detection limit was $36 \mu \mathrm{g} . \mathrm{L}^{-1}$.

The same procedure was used for extraction of citrinin from apple samples (15-75 g) with Penicillium strains.

The antimicrobial activity of citrinin on Bacillus subtilis was tested directly on the silica plates, after UV detection.

Table 1. Recovery of citrinin in liquid yeast medium.

\begin{tabular}{cccc}
\hline $\begin{array}{c}\text { Volume of liquid } \\
\text { yeast medium }(\mathrm{mL})\end{array}$ & $\begin{array}{c}\text { Citrinin } \\
\text { added }(\mu \mathrm{g})\end{array}$ & $\begin{array}{c}\text { Citrinin } \\
\text { detected }(\mu \mathrm{g})\end{array}$ & $\begin{array}{c}\text { Recovery } \\
(\%)\end{array}$ \\
\hline 50 & 18 & 13.2 & 73.3 \\
50 & 9.0 & 5.9 & 65.5 \\
50 & 3.6 & 2.4 & 66.6 \\
50 & 1.8 & 0.9 & 50 \\
50 & 0.9 & 0.3 & 33.3 \\
\hline
\end{tabular}

Developed silica plates were moistened with sterile mobile phase, and then flowed over with Müller-Hinton agar that contained a suspension of $B$. subtilis $\left(10^{6} \cdot \mathrm{mL}^{-1}\right)$. The plates were put in a sterile glass box with $95 \%$ moisture and incubated at $37^{\circ} \mathrm{C}$ for 24 hours. The absence of growth of $B$. subtilis around the spot of citrinin ( $\mathrm{Rf} 0.5$ ) was recorded as a positive inhibitory effect.

Minimal inhibitory concentration (MIC) of citrinin was established by using $1 \mathrm{~mL}$ of a $B$. subtilis suspension $\left(10^{6} \cdot \mathrm{mL}^{-1}\right)$ in Müller-Hinton agar. Ether dilutions of purified citrinin in range of 0.0036-0.216 $\mu \mathrm{g} . \mathrm{mL}^{-1}$ were applied on the surface of the agar and incubated at $37^{\circ} \mathrm{C}$ for 24 hours. The bacteriostatic and bactericidal effects were observed under a binocular microscope (magnification 50 X) (Fig. 1).

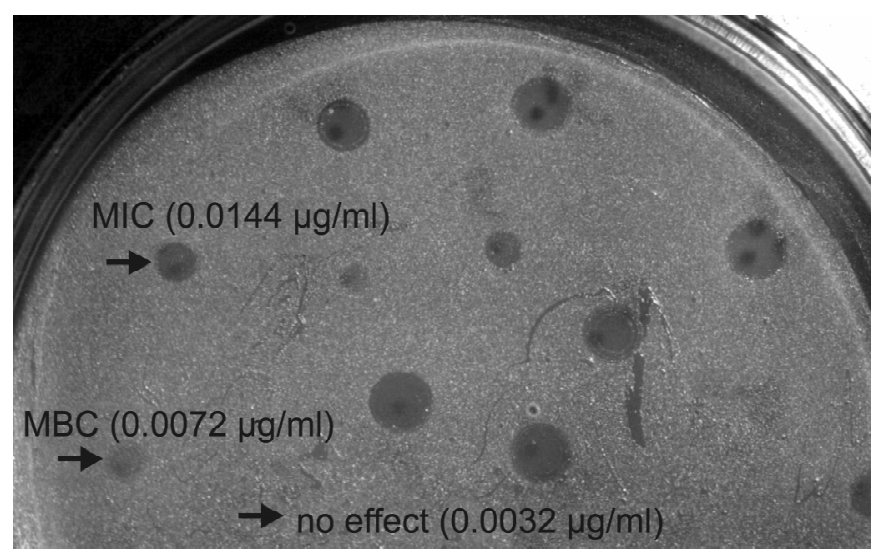

Figure 1. Bacteriostatic (MBS) and bactericidal (MIC) effect of citrinin on Bacillus subtilis (Müller-Hinton agar, incubation 24 hours at $37^{\circ} \mathrm{C}$ ).

\section{RESULTS AND DISCUSSION}

The most frequent contaminants in the apple samples were yeasts (60\%), Penicillium spp. (37\%) and Monilia (14\%). Other moulds, like Aspergillus, Trichotecium, Mucor, Trichoderma and Rhizopus were also isolated, but in low frequency (1-3\%) (Table 2).

Among penicillia, 78\% (29 strains) were Penicillium expansum, 13\% (5 strains) P. roqueforti, 5\% (2 strains) $P$. implicatum and 2\% (1 strain) P. purpurogenum (Table 3).

Citrinin was detected in $19 \%$ of apple samples, in concentrations ranging from 0.05 to $0.24 \mathrm{mg} . \mathrm{kg}^{-1}$. In liquid yeast medium, 38\% (11 strains) of Penicillium expansum were citrinin producers in concentrations ranging from 0.07 to $9.00 \mathrm{mg} \cdot \mathrm{kg}^{-1}$ (Table 3). For P. roqueforti, P. implicatum and P. purpurogenum strains, citrinin production was not detected. Penicillium expansum strains were classified in three categories according 
Table 2. The occurrence of fungi in decaying apples.

\begin{tabular}{lc}
\hline \multicolumn{1}{c}{ Fungal isolates } & ${ }^{\mathrm{x}} \mathrm{N}=100 \%$ of total \\
\hline Penicillium spp. & 37 \\
Monilia spp. & 14 \\
Aspergillus spp. & 1 \\
Trichothecium spp. & 3 \\
Mucor spp. & 1 \\
Trichoderma spp. & 2 \\
Rhizopus spp. & 3 \\
Yeasts & 60 \\
\hline
\end{tabular}

${ }^{\mathbf{x}} \mathbf{N}$ - total number of samples.

Table 3. Citrinin production ability of Penicillium species isolated from decaying apples.

\begin{tabular}{lccc}
\hline $\begin{array}{c}\text { Penicillium } \\
\text { species }\end{array}$ & $\begin{array}{c}{ }^{\mathrm{x}} \mathrm{N}=37 \\
\text { \% of strains }\end{array}$ & $\begin{array}{c}\text { \% of } \\
\text { toxinogenic } \\
\text { strains }\end{array}$ & $\begin{array}{c}\text { Concentration } \\
\text { of CTN } \\
\text { mg.kg-1 }\end{array}$ \\
\hline$P$. expansum & 78 & 38 & $0.07-9.00$ \\
$P$ roqueforti & 13 & - & - \\
$P$. implicatum & 5 & - & - \\
$P$. purpurogenum & 2 & - & - \\
\hline
\end{tabular}

${ }^{x} \mathbf{N}$ - number of Penicillium strains.

to the amount of citrinin produced: low producers $(0.07-0.17$ mg.kg-1 ${ }^{-1}$, intermediate producers (1.08-1.80 mg. $\left.\mathrm{kg}^{-1}\right)$ and high producers (3.00-9.00 mg. $\mathrm{kg}^{-1}$ ) (Fig. 2). Forty five percent of citrinin producer strains were classified in the last category.

The antimicrobial activity of extracted citrinin, established in direct tests on Bacillus subtilis, indicated that bacteriostatic and bactericidal effects were found at concentration of 0.0072 $\mu \mathrm{g} . \mathrm{mL}^{-1}$ and $0.0144 \mu \mathrm{g} . \mathrm{mL}^{-1}$, respectively (Fig. 1).

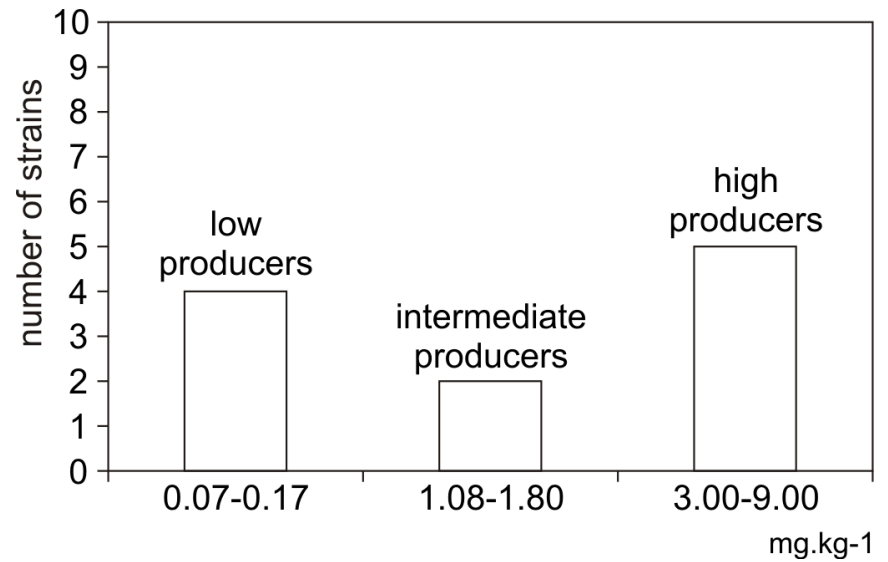

Figure 2. Citrinin producers among Penicillium expansum strains isolated from decaying apples in mg. $\mathrm{kg}^{-1}$.
Citrinin showed toxicological effect on some farm animals. When low concentrations of citrinin $\left(0.01 \mathrm{mg} \cdot \mathrm{kg}^{-1}\right.$ body weight) were given to swine for 57 days, clinical effects and histopatological lesions were not recorded, suggesting that low concentrations of citrinin do not cause health disorders. On the other side, in experimental poisoning of bovine with citrinin in concentrations 0.03 and $0.04 \mathrm{mg} . \mathrm{kg}^{-1}$ added in food, citrinintoxicoses was established (11). Therefore, citrinin concentrations over $0.01 \mathrm{mg} . \mathrm{kg}^{-1}$ might present a potential health hazard, especially in domestic production of apple juices, when decayed fruits are used. On the other hand, citrinin showed a bactericidal effect on Bacillus subtilis in relatively small concentrations $\left(0.0144 \mu \mathrm{g} \cdot \mathrm{mL}^{-1}\right)$. Thus, the toxic effect of citrinin on intestinal microflora and its capability to cause gastrointestinal disorders are important questions that remain open.

A study with 122 Penicilium expansum strains isolated from apples and apple-packing houses in Spain indicated that $46 \%$ of them were able to produce citrinin in the agar plug test. Among these, $73.2 \%$ were isolated from decayed apple samples (16). When the citrinin producer strains were inoculated in apples and apple juices, $73.3 \%$ of them produced citrinin in these products. This means that contamination with spores during apple juice production may result in growth of the mycelium and production of mycotoxins. In our study, penicillia were not isolated from 6 out of 19 citrinin positive samples. The negative samples presented advanced decaying and were expressively contaminated with yeasts. We can assume that yeasts have biological antagonism to Penicillium expansum. Recent attempts for biological control showed that several bacteria and yeasts are capable of controlling blue mould. In particular, the pink yeast, Sporobolomyces roseus is a very good control agent of Penicillium expansum (9). Literature reports that heating apples for $96 \mathrm{~h}$ at $38^{\circ} \mathrm{C}$ will prevent the development of the decay (7). On the other side, heating citrinin in the presence of water at $100^{\circ} \mathrm{C}$ for 30 min causes formation of citrinin $\mathrm{H} 1$, which is ten times more toxic than citrinin (3). There is also recent evidence that surface application of cinnamon oil or potassium sorbate on apples might be potential inhibitors of Penicillium expansum (13). Moreover, apple juices should be stored at low temperature or pasteurised to destroy any contaminating mycelium or spores. In addition, apple juice must be produced under good sanitary conditions.

\section{RESUMO}

\section{Citrininotoxigenicidade de Penicillium sp. isolado de maçãs deterioradas}

Nesse estudo, foi examinada a ocorrência de citrinina e a capacidade de produção do citrinina por cepas de Penicillum spp. isoladas de maçãs deterioradas, recolhidas em pomares domésticos no território da Croácia. De 100 amostras de maçãs examinadas, foram isoladas 37 cepas de Penicillium spp. 
incluindo $P$. expansum, $P$. roqueforti, $P$. impicatum e $P$. purpurogenum. A capacidade de produção de citrinina por 11 cepas de $P$. expansun foi determinada em meio líquido obtendose concentrações variando entre 0,07 e $9,00 \mathrm{mg} \cdot \mathrm{kg}^{-1}$. A citrinina foi detectada em $19 \%$ das amostras de maçãs, com concentração variando entre 0,05 e $0,24 \mathrm{mg} \cdot \mathrm{kg}^{-1}$. O efeito antimicrobiano da citrinina foi determinado em testes com Bacillus subtilis, com zona de inibição variando entre $5 \mathrm{~mm}$ e $1 \mathrm{~cm}$. A concentração mínima inibitória (CMI) foi $0,0072 \mu \mathrm{g} \cdot \mathrm{mL}^{-1}$ para o efeito bacteriostático e $0,0144 \mu \mathrm{g} \cdot \mathrm{mL}^{-1}$ para o efeito bactericida.

Palavras-chave: citrinina, Penicillium expansum, maçãs deterioradas, efeito antimicrobiano.

\section{REFERENCES}

1. Balzer, I.; Bogdanic, C.; Pepeljnjak, S. Rapid thin layer chromatographic method for determining aflatoxin B1, ochratoxin A and zeralenon in corn. J. Assoc. Offic. Anal. Chem., 61: 584-585, 1978.

2. Barnett, H.L. Illustrated genera of imperfect fungi. Burgers publishing company, Minneapolis, 1960.

3. Bentrivedi, A.; Hirota, M.; Doi, E.; Kitabatke, N. Formation of a new toxic compound, citrinin H1, from citrinin on mild heating in water. J. Chem. Soc. Perkin Transaction 1, 18: 2167-2171, 1993.

4. Betina, V. Mycotoxins. Production, Isolation, Separation and Purification. Elsevier, Sci. Publ. Co. Inc., New York, 1984, p.217-236.
5. Cappellini, R.A.; Ceponis, M.J.; Lightner, G.W. Disorders in apple and pear shipments to the New York market. Plant Dis., 7: 852$856,1987$.

6. Castegnaro, M.; McGregor, D. Carcinogenic risk assessment of mycotoxins. Rev. Méd. Vét., 149: 671-678, 1998.

7. Fallik, E.; Grinberg, S.; Gambourg, M.; Klein, J.D.; Lurie, S. Prestorage heat treatment reduces patogenicity of Penicillium expansum in apple fruit. Plant Pathol., 45: 92-97, 1995.

8. Hald, B.; Krogh, P. Analysis and chemical confirmation of citrinin in barley. J. Assoc. Offic. Anal. Chem., 56: 1440-1443,1973.

9. Janisiewicz, W.J.; Peterson, D.L.; Bors, R. Control of storage decay of apples with Sporobolomyces roseus, Plant Dis., 78: 466-470, 1994.

10. Lea, A.G.H. Apple juice. Production and packaging of non carbonated fruit juices and fruit beverages. Ed. by Chapman and Hall, (Ed.2.) Ashurst, P.R., 1995, p.153-196.

11. Ožegovic, L.; Pepeljnjak, S. (1995) Mikotoksikoze. Školska knjiga, Zagreb, 1995, p.105-108.

12. Raper, K.B.; Thom, C. A manual of the penicillia. The Williams \& Wilkins company, Baltimore, 1949.

13. Ryn, D.J.; Holt, D.J. Growth inhibition of Penicillium expansum by several commonly used food ingredients. J. Food Prot., 56: 862867, 1993.

14. Samson, R.A.; Hoekstra, E.S.; van Oorschot, C.A.N. Introduction to food-borne fungi. Centraalbureau Voor Schimmelcultures, Institute of the Royal Netherlands Academy of Arts and Science, 1981.

15. Sanderson, P.G.; Spotts, R.A. Postharvest decay of winter pear and apple fruit caused by species of Penicillium. Phytopathology, 85: 103-110, 1995.

16. Vinas, I.; Danon, J.; Sanchis, V. Citrinin-producing capacity of Penicillium expansum strains from apple-packing house of Lerida (Spain). Int. J. Food Microbiol., 19: 153-156, 1993. 